\title{
左腋窩動脈-左前下行枝バイパス術の臨床成績と グラフト血流評価の検討
}

藤 解 邦 生 洲 鎌 盛一

静脈グラフトを用いた低侵襲冠動脈バイパス術は内胸動脈がグラフトとして不当である場合に有効とされる が, 現在のところ静脈グラフトの開存率を含めた臨床成績は明らかにされていない. 当施設で経験した大伏 左静脈（SVG）を用いた左腋窩動脈-左前下行枝（LAD）バイパス術 5 例の臨床成績について検討した。年 齢は平均 72.6 歳, 患者背景は, 心臓手術既往 2 例, 脳血管障害 1 例, 食道癌術後（胸骨後再建） 1 例, 腎不 全 1 例であった，術式は，SVG を腋窩動脈から胸腔を通し LAD に吻合した．手術時間は平均 186 分であっ た. 腎不全症例を除いた 4 例で術後冠動脈造影を施行しグラフト開存を確認, 腎不全症例は経胸壁心臓超音 波検査でグラフトと LAD の血流を認め, 5 例とも退院した. 術後平均 10.4 カ月の観察期間中, 手術 6 カ月 後にグラフト不全による死亡を 1 例認めた以外は冠動脈合併症なく経過した. グラフト経路が長いため圧迫 などによる血栓形成の予防が重要と考えられた. 鎖骨下パルスドプラ法によるグラフト血流評価を行った ところ,グラフト径 (平均) $4.73 \mathrm{~mm}$, 収縮期最高血流速 (平均) $22.4 \mathrm{~cm} / \mathrm{s}$, 拡張期最高血流速 (平均) $22.1 \mathrm{~cm} / \mathrm{s}$ の結果であった. 本法は経胸壁超音波検査によるグラフトの最高血流速を経時的に測定すること でグラフト血流を評価することが可能であると考えた。，ハイリスク症例に対する静脈グラフトを用いた低侵 襲冠動脈バイパス術は有効であり，グラフト血流の評価に経胸壁超音波検査は有用であると考えられた，日 心外会誌 35 巻 2 号 : 76-80 (2006)

Keywords：低侵襲冠動脈バイパス術, 左腋窩動脈-左前下行枝バイパス術, 静脈グラフト,ドプラ法

\section{Results and Assessments of Saphenous Vein Grafts Flow with Left Axillary to Left Anterior Descending Coronary Artery Bypass}

Kunio Toge and Moriichi Sugama (Department of Cardiovascular Surgery, Makiminato Central Hospital, Urasoe, Japan)

Axillary artery-to-coronary artery bypass using a saphenous vein graft provides a simple and safe method of applying a minimally invasive coronary bypass grafting procedure when the internal thoracic artery is not an adequate conduit. Although this may allow use of a minimally invasive coronary bypass procedure, the patency of this technique is unknown. The purpose of this study was to review our experience in the clinical results and problems with left axillary artery to left anterior descending coronary artery bypass. Since 1999 we have applied this procedure in 5 patients (with a mean age of 72.6 years). All patients were high-risk candidates because of cerebral infarction, depressed renal function, previous heart operation, or previous surgical treatment of esophageal carcinoma. The saphenous vein was anastomosed to the left axillary artery, where it entered the thorax and continued to the left anterior descending coronary artery. The mean operation time was $3.1 \mathrm{~h}$ (range: 2.3 to $4.7 \mathrm{~h}$ ). Angiography or thallium studies or Doppler echocardiography were performed to confirm graft patency. Postoperative angiography showed all grafts to be patent. All patients were discharged. During a mean follow-up period of 10.4 months, one patient in whom graft distributed over the subclavian vein died due to failure of the graft 6 months after the operation. Four patients were free from cardiac events. Axillary artery-to-coronary artery bypass using the saphenous vein is an effective and safe technique for high-risk patients if we pay attention to the course of the graft. In an effort to evaluate flow characteristics of the saphenous vein grafts (SVG) after the operation, we used transcutaneous ultrasound study with Doppler flow velocimetry of SVG. The diameter of the vessel, systolic peak velocity, diastolic peak velocity, and velocity ratio were recorded. Use of this may allow noninvasive identification of the bypassing grafts and comparison of their postoperative blood flow waveforms in patients following minimally invasive direct coronary artery bypass (MIDCAB). It can also be performed repeatedly to monitor the patient's clinical course after surgery. Jpn. J. Cardiovasc. Surg. 35 : 76-80 (2006)

2005 年 8 月 2 日受付, 2005 年 10 月 5 日採用

牧港中央病院心臟血管外科

于 901-2131 浦添市字牧港 1199 
表 1 手術成績

\begin{tabular}{ccccccc}
\hline 症例 & 年齢/性 & $\begin{array}{c}\text { 手術時間 } \\
\text { (分) }\end{array}$ & $\begin{array}{c}\text { 術後グラフト } \\
\text { 造影 }\end{array}$ & 合併症 & $\begin{array}{c}\text { 病院 } \\
\text { 死亡 }\end{array}$ & 転帰 \\
\hline 1 & $65 / \mathrm{M}$ & 280 & patent & - & - & グラフト不全により死亡 \\
2 & $67 / \mathrm{M}$ & 210 & patent & 気胸 & - & 生 \\
3 & $79 / \mathrm{M}$ & 140 & patent & 肺炎 & - & 生 \\
4 & $76 / \mathrm{M}$ & 150 & patent & 一過性心房細動 & - & - \\
5 & $76 / \mathrm{F}$ & 150 & patent* & - & 生 \\
\hline
\end{tabular}

* 腎不全症例のため造影施行せず。心筋シンチグラフィー, 経胸壁心臟超音波検査でグラフ 卜開存を確認した.

低侵襲冠動脈バイパス術 (minimally invasive direct coronary artery bypass : MIDCAB) は手術侵襲が少な いため, 高齢者, 腎不全, 低左室機能などの合併症を有す る症例に有効とされているが，静脈グラフトを用いた MIDCAB は適応症例が少なく, 現在のところ十分な検討 がなされていない1). 左内胸動脈（LITA）を使用した冠 動脈バイパス術 (CABG) 既往，LITA 剝離時の血管損 傷, 血流不足などの理由によりグラフトとしてLITA が 不当である場合や，高齢者やハイリスク症例などには，静 脈グラフトを用いて左腋窩動脈から左前下行枝へバイパス する術式は，簡便で有効な術式である ${ }^{1 \sim 4)}$ 。今回，われわ れは大伏在静脈（SVG）を用いた左腋窩動脈-左前下行枝 （LAD）バイパス術 5 例の臨床成績とグラフト血流評価に ついて検討した。

\section{対象と方法}

1999 年 8 月から 2005 年 2 月までの期間中に当施設て SVG を用いた左腋窩動脈-LAD バイパス術を施行した 5 症例を対象とした。症例の内訳は男性 4 例, 女性 1 例, 手 術時年齢は平均 72.6 歳 (65～79 歳), 術後経過年数は 10.4 （4～18）力月であった.

MIDCAB の適応とした患者背景は, 心臓手術既往 2 例 (胸骨正中切開による CABG 1 例，人工弁置換術 1 例), 脳血管障害 1 例, 食道癌術後（胸骨後再建） 1 例, 腎不全 1 例であった。

手術体位は仰臥位とし，下肢はSVGを採取しやすいよ うにやや外転させた。麻酔は両肺換気で行い，左肋間操作 時に手技が困難な場合は適宜，手動換気にて調節した。 SVG は，中枢側を左腋窩動脈に吻合後，1例を除き鎖骨 下静脈の下へ誘導し, 胸腔内を経由し LAD へ伆合した。

グラフト血流評価には $8 \mathrm{MHz}$ の高周波探触子を用いた 経胸壁超音波検査を施行した，左鎖骨下アプローチにより グラフトを描出しグラフト径を計測，パルスドプラ法にて 収縮期最高血流速, 拡張期最高血流速と流速比（拡張期最 高血流速/収縮期最高血流速）を計測した.
表 2 鎖骨下パルスドプラ法によるグラフト血流評価 (平均値)

\begin{tabular}{ll}
\hline グラフト径 & $4.73(3.7 \sim 5.6) \mathrm{mm}$ \\
収縮期最高血流速 & $22.4(13.4 \sim 31.0) \mathrm{cm} / \mathrm{s}$ \\
拡張期最高血流速 & $22.1 \quad(18.5 \sim 26.2) \mathrm{cm} / \mathrm{s}$ \\
流速比 & 1.07 \\
\hline
\end{tabular}

\section{結果}

\section{1. 手術成績}

手術時間：平均 $186 （ 140 ２ 80 ）$ 分，術中出血量；平均 $374 （ 60$ 600） $\mathrm{ml}$ であった。

術後合併症は気胸 1 例, 肺炎 1 例, 一過性心房細動 1 例 認められ，在院死亡は 0 例であった（表 1).

\section{2. グラフト成績}

腎不全症例を除く 4 例で術後冠動脈造影を施行した. 全 例でグラフト開存を確認した。腎不全症例は心筋シンチグ ラフィーで心機能改善を認め，経胸壁心臟超音波検査では グラフトと LAD の血流を確認し，グラフト開存が示唆さ れた。術後平均 10.4 力月の観察期間内にグラフト閉塞, 冠動脈解離による死亡を 1 例認めた以外は冠動脈, グラフ 卜合併症なく経過した（表 1).

\section{3. 鎖骨下パルスドプラ法によるグラフト血流評価}

鎖骨下パルスドプラ法によるグラフト血流評価を行った ところ SVGの検出率は $100 \%$ (4/4 例) であった。術後 平均 10.3 カ月後のグラフト径は平均 $4.73(3.7 \sim 5.6)$ $\mathrm{mm}$, グラフトの収縮期最高血流速は平均 $22.4(13.4 \sim 31.0) \mathrm{cm} / \mathrm{s}$, 拡張期最高血流速 は平均 $22.1(18.5 \sim 26.2) \mathrm{cm} / \mathrm{s}$ であった。流速比 (D/S) の平 均は 1.07 であり,やや拡張期優位という結果を得た（表 2). 3 例 (75\%) は拡張期優位の血流パターンを示した （図 1）が，1例（25\%）で収縮期優位（図 2）を認めた。

\section{考察}

\section{1. グラフト成績と問題点}

MIDCAB は低侵襲で有効であるが，静脈グラフトを用 いた場合，その開存率が大きな問題となる．今回の検討で 


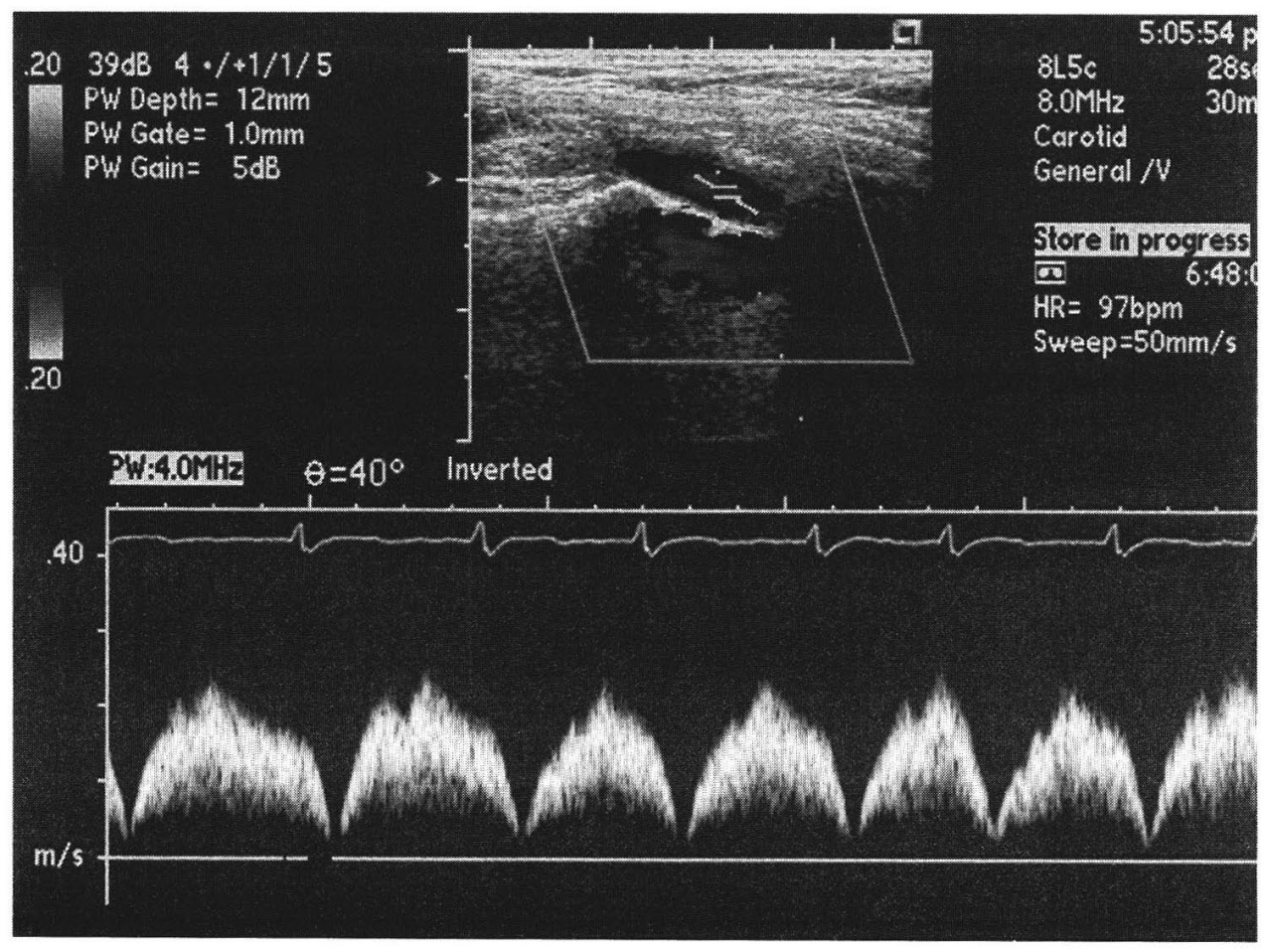

図 1 拡張期優位の血流速波形

収縮期最高血流速 $23.9 \mathrm{~cm} / \mathrm{s}$, 拡張期最高血流速 $26.2 \mathrm{~cm} / \mathrm{s}$, 流速比 1.1 .

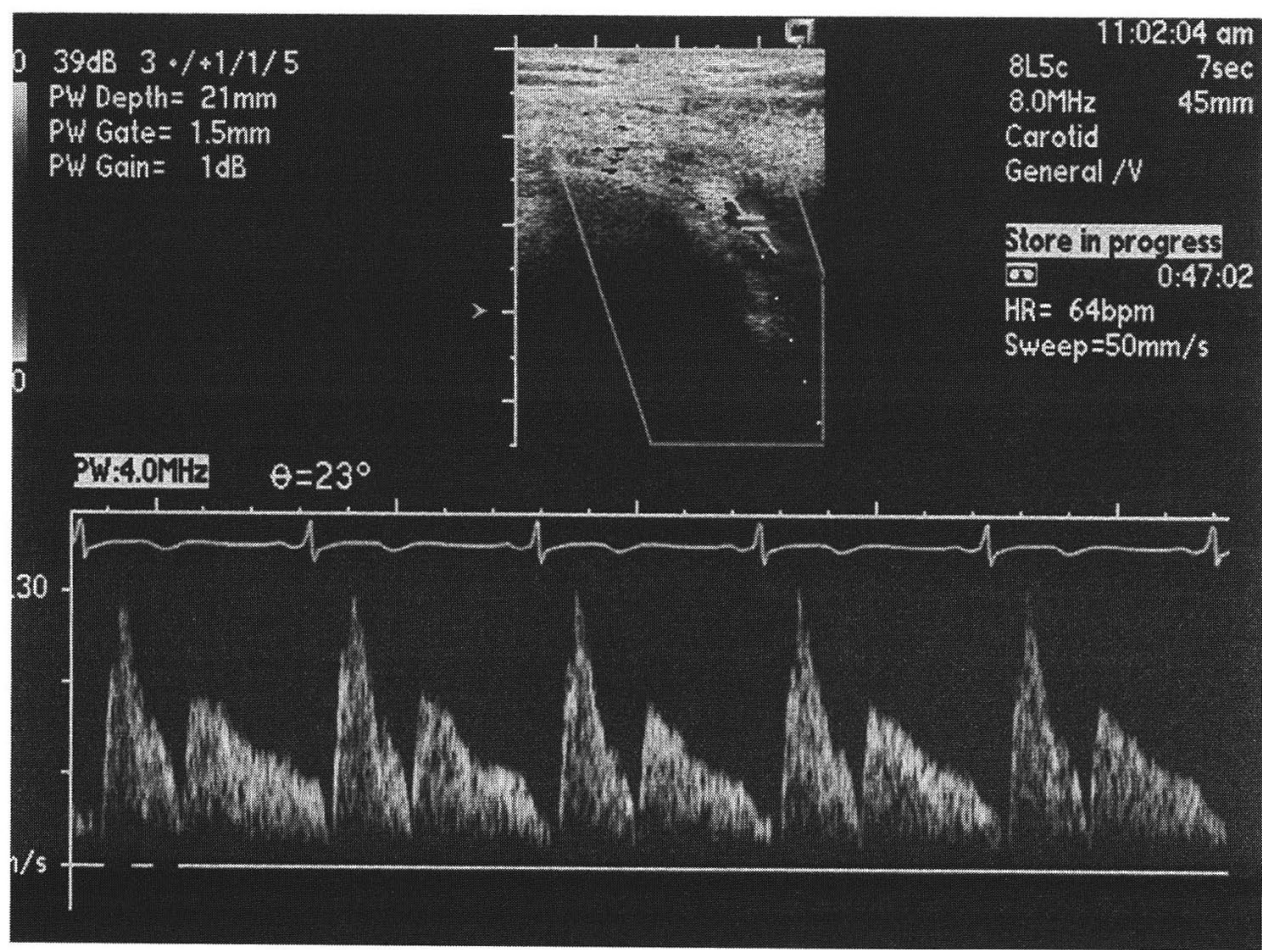

図 2 収縮期優位の血流速波形

収縮期最高血流速 $31.0 \mathrm{~cm} / \mathrm{s}$, 拡張期最高血流速 $18.5 \mathrm{~cm} / \mathrm{s}$, 流速比 0.60 .

は，術後 6 カ月目に緊急冠動脈バイパス術を要したグラフ ト閉塞例を 1 例認めた。1999 年に施行した本症例はグラ フト経路が鎖骨下静脈の上方を経由し，冠動脈解離を認め
た例であった.グラフト閉塞の要因は，グラフト圧迫によ る血栓閉塞か，もしくは原因不明の冠動脈解離によるグラ フト血流の低下が考えられた。 


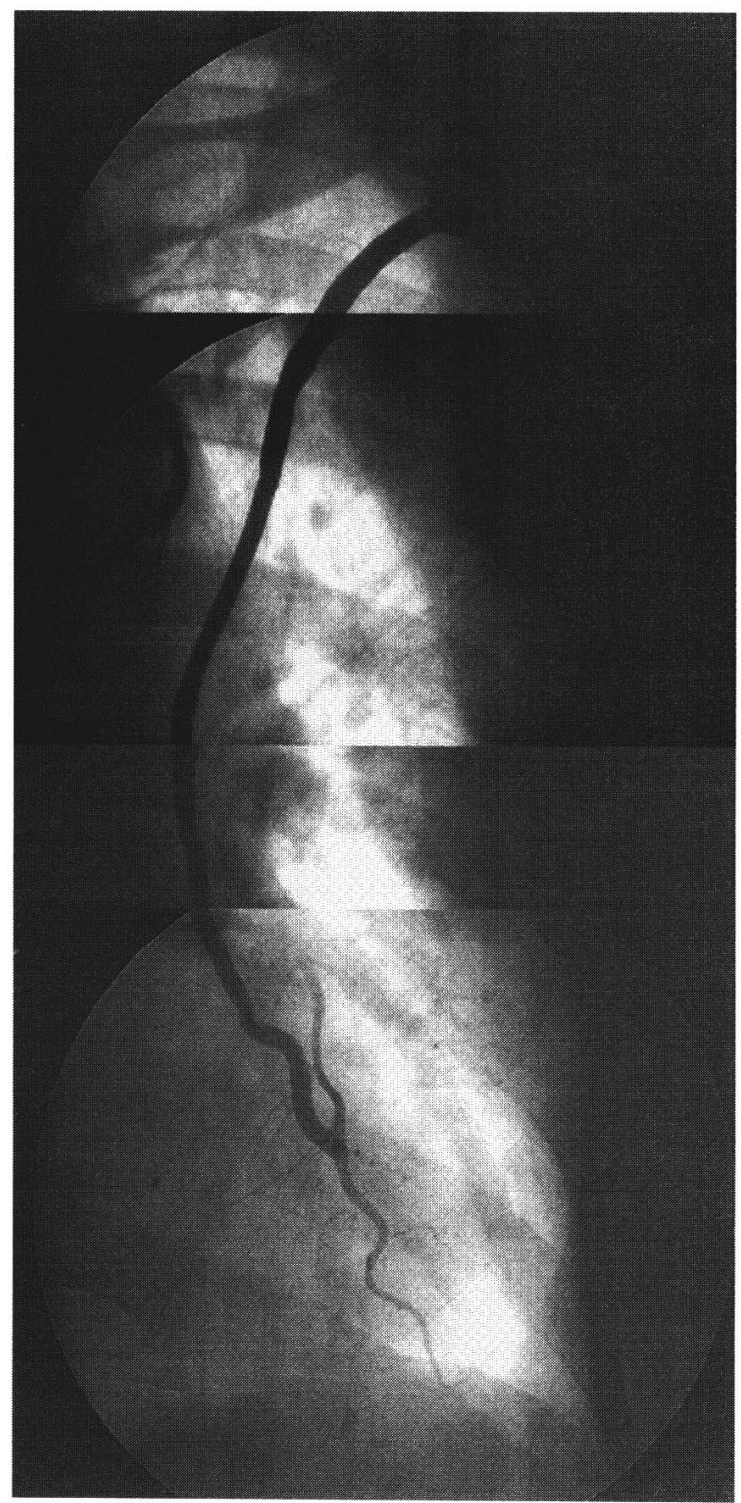

図 3 グラフト造影所見

2001 年に Magovern らは鎖骨下静脈の下方を経由する ことでグラフト閉塞を予防できると報告5)しており，当施 設においても，SVGが鎖骨下静脈の下方を経由した 2003 年以降の 4 症例はグラフト開存を維持し，良好な結果を得 た。これらより，鎖骨下静脈の下方を経由する経路はグラ フトへの圧迫も少なく,グラフト開存率の上昇につながる と考えられた。

本法はグラフト経路がとりわけ長い（図 3）ため，圧迫 や捻れに留意することが重要である。

\section{2. グラフト血流評価}

近年, $\mathrm{CABG}$ 後グラフト血流評価として低侵襲である 超音波ドプラ法が注目されている(6) が, MIDCAB で使用 したSVGに関する報告は少ない。

Magovern らはSVGのパルスドプラ波形は拡張期有意
の 2 相性であったと報告している5 が，当施設においても 3 例 $(75 \%)$ で同様の結果を得た。しかし，収縮期優位の 波形を 1 例（25\%）認めた。Tsai らはグラフトの冠動脈 吻合部により近いところで典型的な拡張期有意の 2 相波を 示すと報告7しており，当施設における収縮期優位の 1 例 は，描出部位が腋窩動脈に近接していた可能性が示唆され た。笹橋らも指摘するように ${ }^{8)}$, グラフトの血流パターン は描出部位で異なるため，これを一定にしなければ血流パ ターンを検討するうえで正確さを欠くものとなるであろ う.

グラフト狭窄病変を有する場合, 拡張期最高血流速は低 下すると報告されて抢り ${ }^{6)}$, 収縮期優位の血流パターンを 示した例はグラフトの狭窄病変を示唆している可能性があ るが，グラフト造影にて開存を認めており否定的であつ た. グラフトの狭窄を示唆する所見としては, 最高血流速 の低下のほかにグラフト内径の縮小があげられ ${ }^{81}$, 今後も グラフト血流と血管内径を経時的に測定していくことで狭 窄の有無を判定できると考えた。

MIDCAB の対象となる患者は高齢者やハイリスク例が 多く, 反復する㝴動脈造影が困難となる症例も少なくな い.そのため，低侵襲であり，より簢便に行える静脈グラ フトの血流評価法を確立することはハイリスク患者に大き な利益をもたらすと考えた。遠隔期開存率が未知である左 腋窩動脈-LAD バイパス術に拀いて, 簡便で反復可能な経 胸壁超音波検査はグラフト病変を把握するうえで大きな意 義をもつと考えた。

\section{結語}

当施設にて経験したハイリスク症例に対する静脈グラフ 卜を用いた低侵襲冠動脈バイパス術（左腋窩動脈-LAD バ イパス術）について検討した。

低侵襲で反復可能な経胸壁超音波検査はグラフト血流評 価に有用であると考えられた。

\section{文献}

1) Knight, W. L., Baisden, C. E. and Reiter, C. G. : Minimally invasive axillary-coronary artery bypass. Ann. Thorac. Surg. 63 : 1776-1777, 1997.

2）川田哲嗣, 阿部毅寿, 上田高士ほか：左前下行枝への左内胸 動脈グラフト開存, difficult descending aorta 下での回旋 枝領域に対する心拍動下再冠状動脈バイパス術. 胸部外科 55:811-813, 2002.

3) Morishita, A., Shimakura, T., Miyagishima, M. et al. : Minimally invasive direct redo coronary artery bypass grafting. Ann. Thorac. Cardiovasc. Surg. 8: 209-212, 2002.

4) Machiraju, V. R., Culig, M. II., Heppner, R. L. et al. : Value of reversed saphenous vein in minimally invasive direct coronary artery bypass graft procedures. Ann. Thorac. Surg. 65 : 625-627, 1998. 
5) Magovern, J. A., Hunter, T. J. and Yoon, P. D. : Clinical results with left axillary to left anterior descending coronary artery bypass. Ann. Thorac. Surg. 71: 561564,2001 .

6) Chirillo, F., Bruni, A., Balestra, G. et al. : Assessment of internal mammary artery and saphenous vein graft patency and flow reserve using transthoracic Doppler echocardiography. Heart 86 : 424-431, 2001.
7) Tsai, T. P., Ueng, K. C., Yu, J. M. et al. : Comparison of the postoperative blood flow waveforms of the bypassing grafts in patients following minimally invasive direct coronary artery bypass. Chest 121: 951-956, 2002.

8）笹橋 望, 安藤史隆, 岡本文雄ほか: 冠状動脈バイパス術後 の静脈グラフト血流評価一内胸動脈グラフト症例との比 較. 胸部外科 $55 ： 461-465,2002$. 